\title{
Comparative study of the degree of differentiation of neuroblastoma and mean numbers of nucleolar organiser regions
}

\author{
M EGAN, F RAAFAT, J CROCKER, D WILLIAMS \\ From the Birmingham Children's Hospital; and East Birmingham Hospital
}

SUMMARY Twenty confirmed cases of childhood neuroblastoma diagnosed over six years were reviewed and classified according to the subtyping proposed by Shimada et al. The tumours were stained using a silver colloid method for nucleolar organiser regions (NORs), and the mean number of NORs for every 200 cells was calculated. The correlation between the mean number of NORs and histology and survival was studied. There was a significant correlation between the mean numbers of NORs and differentiation, and with the mitosis-karyorrhexis index (MKI) in the stroma poor group $(p=0.01-0.001)$. A trend to increased survival with decreased numbers of NORs was observed in the study group as a whole (rank order of correlation $=-0.57, p=0.05-0.02$ ). It is suggested that mean number of NORs is of prognostic value in neuroblastomas.

Neuroblastoma is one of the commonest childhood malignant diseases. Several clinical factors such as age, stage, and site have been shown to affect prognosis. ${ }^{\prime 2}$ A better outcome is associated with young age, stages I, II, or IVs disease, or thoracic, cervical, or pelvic primary sites. It is generally agreed that the histological differentiation of neuroblastomas is associated with improved prognosis, ${ }^{4-9}$ and recently Shimada et al devised a classification based on the degree of differentiation, which they found to be of prognostic value. ${ }^{3}$ This is a modification of Beckwith and Martin's grading system which has been used when relating histological differentiation to prognosis, but which places greater emphasis on the degree of stromal development and also quantifies the mitoses and karyorrhectic cells as an index.

We used this histological classification system ${ }^{1}$ to study the correlation between tumour differentiation and nucleolar organiser regions (NORs) in our series of patients.

\section{Material and methods}

All 20 cases of neuroblastoma and ganglioneuroblastoma diagnosed at Birmingham Children's Hospital between 1980 and 1986 were reviewed by examining routine histological sections. Material from adrenal primary tumour sites was preferentially studied, and in

Accepted for publication 5 January 1988 all cases the diagnosis had been established by a combination of clinical, histological, immunohistochemical, biochemical and ultrastructural methods. There was no standardisation of therapeutic regimens in our series and no attempt to assess the effect of treatment.

All the tumours were classified histologically according to the system proposed by Shimada et al (Table 1). The criteria used for regarding a neuroblastic cell as differentiating were: nuclear enlargement, vesicular nuclei with dispersed chromatin, appearance of nucleoli, development of cytoplasm, and formation of cytoplasmic processes. The stroma poor group were also given a mitosis-karyorrhexis index (MKI) by counting the number of mitoses and karyorrhexis every 5000 cells and assigning them to three classes: low (less than 100 for every 5000 cells), intermediate ( $100-200$ for every 5000 cells), high (more than 200 for every 5000 cells).

Formalin fixed paraffin sections were then examined using the silver colloid technique as follows. Sections of routinely processed, formalin fixed, paraffin embedded blocks were cut $(3 \mu \mathrm{m})$, dewaxed in xylene, and hydrated through ethanols to deionised distilled water. The silver colloid solution for staining NORs was prepared by dissolving galatin in $1 \mathrm{~g} / \mathrm{dl}$ aqueous formic acid at a concentration of $2 \mathrm{~g} / \mathrm{dl}$; this solution was mixed $1 / 2$ volumes, with $50 \mathrm{~g} / \mathrm{dl}$ aqueous silver nitrate to obtain the final working solution. This was dropped on to the sections and left for 60 minutes at 
Table 1 Summary of histological classification used in this study

\begin{tabular}{ll}
\hline Stroma rich & Stroma poor \\
\hline Well differentiated & $\begin{array}{c}\text { Differentiating (more than } 5 \% \text { differen- } \\
\text { tiating cells) } \\
\text { Undifferentiated (less than } 5 \% \text { differen- } \\
\text { tiating cells) }\end{array}$ \\
Focal nodular &
\end{tabular}

Table 2 The distribution of histological subtypes

\begin{tabular}{ll}
\hline Neurofibrillary & No of patients \\
\hline Stroma rich: & \\
Well differentiated & 0 \\
Intermixed & 5 \\
Focal nodular & 0 \\
Stroma poor: & \\
Differentiating & 10 \\
Undifferentiated & 5 \\
\hline
\end{tabular}

room temperature under safelight conditions, after which the sections were washed with distilled deionised water and counterstained with Mayer's haemalum. The sections were taken to xylene and
Table 3 MKI for stroma poor cases

\begin{tabular}{llll}
\hline Stroma poor & Low & Intermediate & High \\
\hline Differentiated & 5 & 2 & 3 \\
Undifferentiated & 1 & 1 & 3 \\
Total & 6 & 3 & 6 \\
\hline
\end{tabular}

Table 4 NOR numbers, age, stage and survival for stroma rich cases

\begin{tabular}{llll}
\hline NOR & $\begin{array}{l}\text { Age } \\
\text { (years) }\end{array}$ & Stage & $\begin{array}{l}\text { Survival } \\
\text { (months) }\end{array}$ \\
\hline 12 & 4 & IV & 10 \\
12 & 12 & IV & 16 \\
12 & 10 & IV & 32 \\
$12 \cdot 1$ & 9 & IV & 34 \\
$12 \cdot 0$ & 2 & III & $72+$ \\
\hline
\end{tabular}

mounted in a synthetic medium. The usual controls were performed as previously described. ${ }^{10}$

The NORs were visualised as dots within the nuclei of the cells in each case. Previous pilot studies had shown that 200 cell samples were representative and 200 cells were examined from randomly selected fields using a $\times 100$ oil immersion lens and a graticule. The mean number of NORs in each cell was then cal-

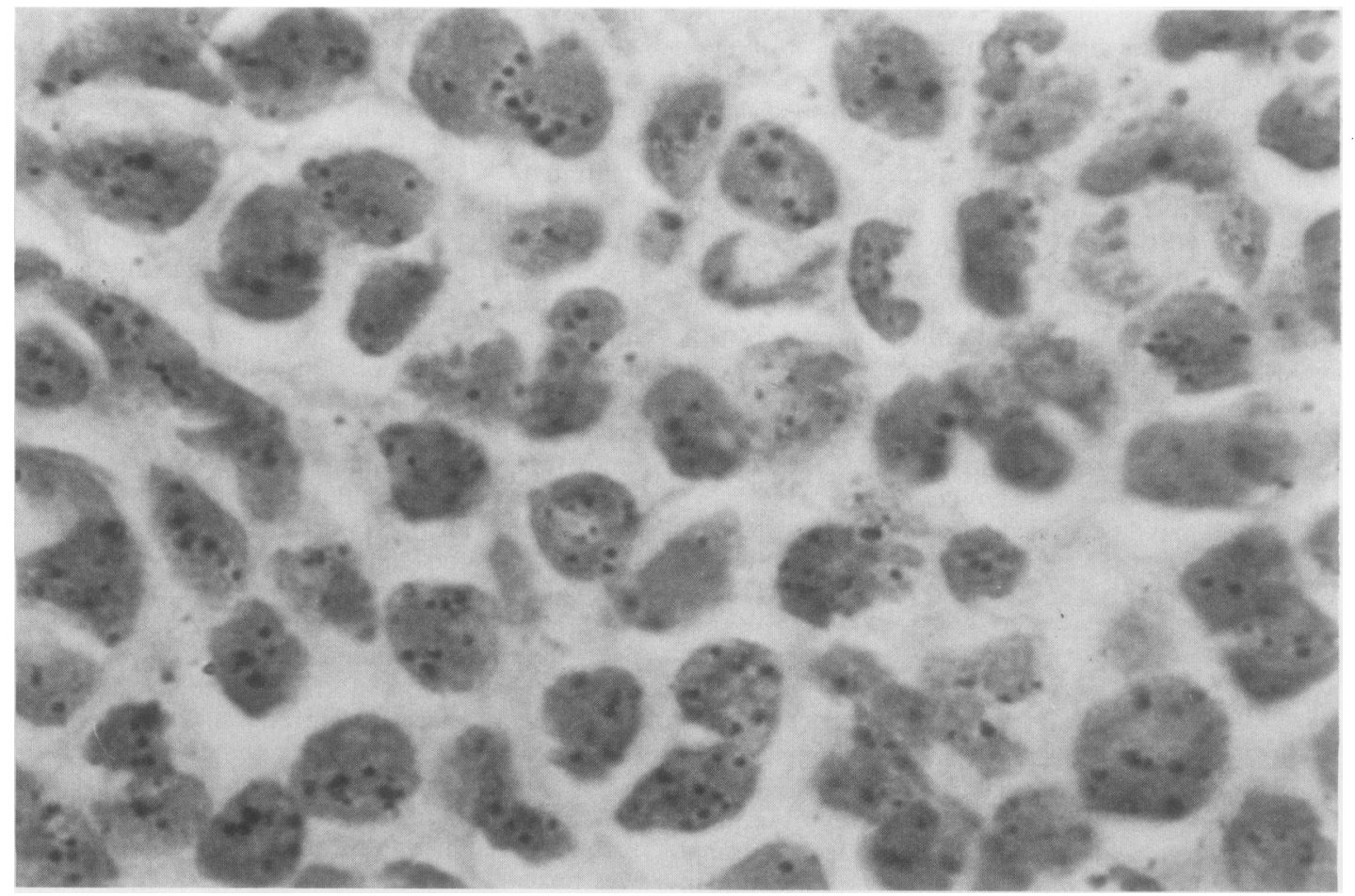

Fig 1 Differentiating stroma poor neuroblastoma stained with silver colloid technique showing numerous NORs within cell nuclei. 


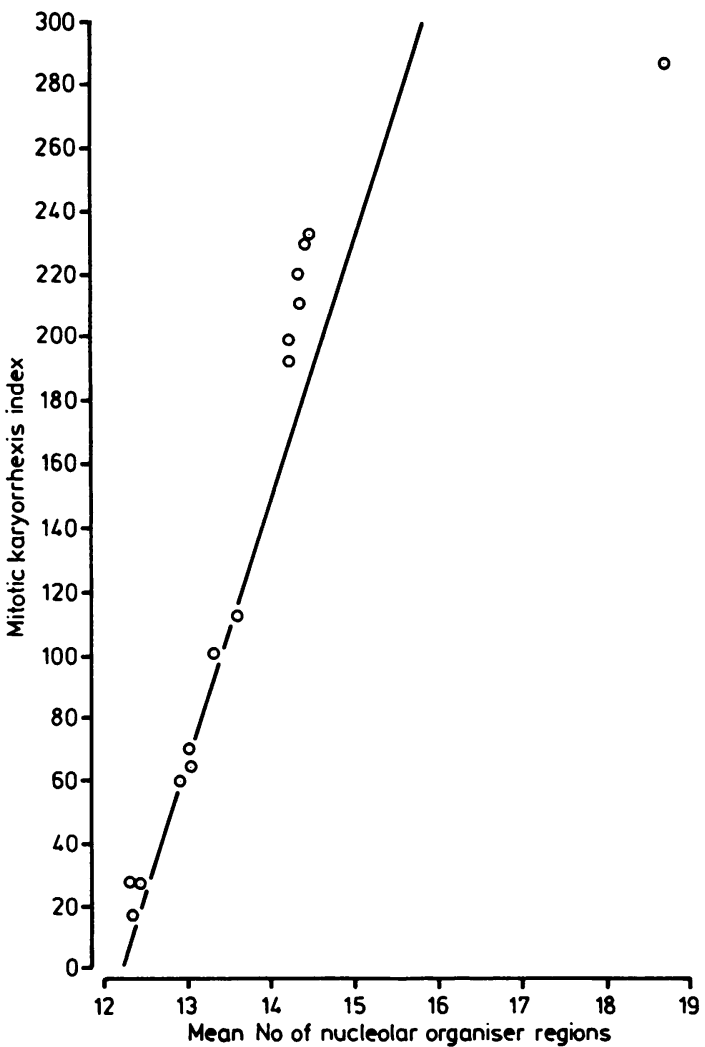

Fig 2 Scatter diagram to show correlation between $M K I$ and mean number of NORs for stroma poor cases (correlation coefficient $=0.702$ ).

culated. In keeping with the earlier work, ${ }^{10}$ inter- and intraobserver error was between $2 \%$ and $5 \%$.

Table 5 Contingency table of mean numbers of NOR and MKI

\begin{tabular}{lllll}
\hline MKI & $\begin{array}{l}\text { Mean No } \\
\text { of NORs }\end{array}$ & $\begin{array}{l}\text { Age } \\
\text { (months) }\end{array}$ & Stage & $\begin{array}{l}\text { Survival } \\
\text { (mon- } \\
\text { ths) }\end{array}$ \\
\hline 15 & $12 \cdot 4$ & 10 & IV & 36 \\
25 & $12 \cdot 4$ & 8 & IV & 64 \\
25 & $12 \cdot 5$ & 11 & III & 36 \\
60 & $12 \cdot 8$ & 48 & III & $18+$ \\
63 & $12 \cdot 9$ & 14 & IV & 20 \\
69 & $12 \cdot 9$ & 48 & IV & 72 \\
100 & $13 \cdot 0$ & 2 & IV & $64+$ \\
110 & $13 \cdot 2$ & 48 & IV & 20 \\
190 & $13 \cdot 4$ & 36 & IV & 9 \\
201 & $13 \cdot 4$ & 5 & IV & 12 \\
210 & $13 \cdot 5$ & 2 & IV & 72 \\
220 & $13 \cdot 5$ & 72 & IV & 1 \\
225 & $13 \cdot 6$ & 24 & IV & $0 \cdot 5$ \\
230 & $13 \cdot 7$ & 6 & IV & 4 \\
290 & $18 \cdot 5$ & 14 & II & 24 \\
\hline
\end{tabular}

\section{Results}

Table 2 shows the distribution of tumours among the different histological subtypes in our study group and table 3 the distribution of the MKI within the stroma poor group. Table 4 shows the NOR numbers, age, stage, and survival for the stroma rich cases. The mean numbers of nucleolar organiser regions for the stroma rich cases was 12.02 (range $12 \cdot 0-12 \cdot 1$ ). The mean number of NORs for the stroma poor group was 13.4 (range 12.4-18.5) (fig 1). Table 5 shows the contingency table for MKI and the mean number of NORs for each stroma poor case examined together with their respective ages, stages, and survival.

There was no significant difference between the MKI and number of NORs using the $\chi^{2}$ test, and the correlation coefficient (r) was $\mathbf{0 . 7 0 2}$ (regression of $y$ on $\mathrm{x}: \mathrm{y}=454+43.8 \times$. Regression of $\mathrm{x}$ on $\mathrm{y}: \mathrm{x}=11.9+$ 1.12E-2Y) (fig 2). The rank order correlation for NORs and survival in months was $-0.57(\mathrm{t}=-2,4 \mathrm{p}$ $=0.05-0.02$ ) (fig 3). Student's $t$ test was used to examine the mean number of NOR's from the stroma rich and stroma poor cases. The difference was significant $(p=0.01-0.001)$. Stage for stage, no

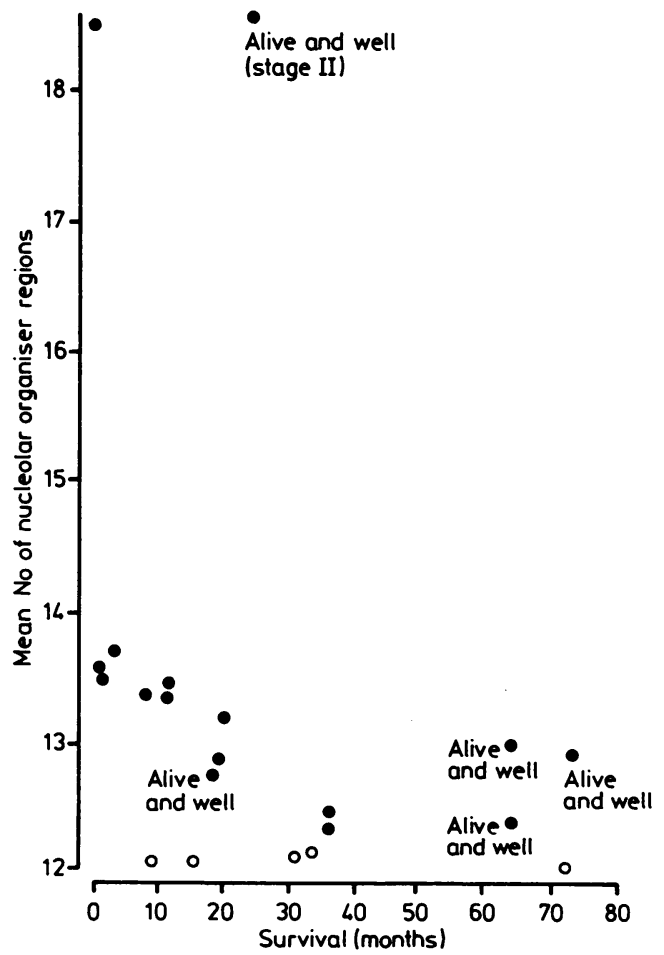

Fig 3 Scattergram to show association between survival (months) and mean numbers of NORs. Rank order correlation - minus 0.57. $(p=0.05-0.02)(\bullet=$ stroma poor, $\mathrm{O}=$ stroma rich). 
difference in survival was observed in the study group for stroma rich and stroma poor cases.

\section{Discussion}

NORs are loops of DNA which occur in the nuclei of cells and which posses ribosomal RNA (rRNA) genes; they are the sites which hybridise with rRNA and are of importance with respect to the ultimate synthesis of protein. ${ }^{10}$ The molecules thought to be associated with NORs include RNA polymerase I, C23 protein, and a molecule similar to $\mathrm{C} 23$ protein but with a smaller molecular size ( $100 \mathrm{Kd}$ compared with $110 \mathrm{Kd}$ for $\mathrm{C} 23$ protein). An $80 \mathrm{Kd}$ molecule has also been recently described. The clinical importance of these NOR associated proteins is rather uncertain but they have been observed for over a decade in chromosomal metaphase spreads and are best visualised using a silver colloid technique. They have previously been the province of cytogenetecists until modifications enabled a one step method to be applied to paraffin sections at $20^{\circ} \mathrm{C}$ without the previously troublesome background staining deposit..$^{1-13}$

The method has been used in the investigation of certain malignant tissues in man. Crocker and Nar applied the technique to non-Hodgkin's lymphomas and were able to distinguish high and low grade histological variants of non-Hodgkin's lymphomas. ${ }^{10}$ Crocker and Skilbeck then applied the method to melanocytic lesions of skin and found that naevocellular naevi and melanocarcinoma have significantly different mean numbers of NORs, the latter possessing many more NORs per nucelus than the former. ${ }^{14}$ Egan et al subsequently applied the technique to small round cell tumours of childhood, ${ }^{15}$ fibrous proliferations and low grade fibrosarcoma of childhood, ${ }^{16}$ tumours of skin ${ }^{17}$ and myoepithelial cells of breast, ${ }^{18}$ and found mean numbers of NORs to be diagnostically useful. The prognostic importance of NORs is still to be determined, but it seems that in the case of Ewing's sarcoma of childhood, there is no prognostic importance. ${ }^{19}$ Studies of the prognostic importance of NORs in rhabdomyosarcoma, lymphoma, and granulosa cell tumours are currently under way.

In the present study the classification used was simple and reproducible in our hands with minimal intra- or interobserver differences of classification. In contrast to the findings of Shimada, our smaller study group did not contain any focal nodular or well differentiated stroma rich groups, and there were proportionally slightly more stroma poor cases. There were, however, significant differences between the mean numbers of NORs in the stroma rich and stroma poor neuroblastomas and a close correlation between NORs and MKI in stroma poor cases. The differences between stroma rich and stroma poor cases are such that a formal count is necessary, as pronounced differences between NOR numbers observed in other instances $^{101516}$ were not present. Significance apart, presented with observer error of up to $5 \%$, it is clear that NOR ranges of stroma rich and stroma poor cases may overlap. This may limit the practical applications of ennumeration of NORs in this situation, and certainly the quickest method of differentiating between stroma rich and stroma poor subgroups is by light microscopy alone.

With respect to the clinical importance of NORs in the stroma poor subgroup, studies using this classification ${ }^{120}$ have shown stroma poor cases to have a worse prognosis than stroma rich cases. The prognosis of these stroma poor cases is inversely related to the MKI. In our study stroma rich cases had the least mean numbers of NORs and stroma poor cases with increasing MKI had increasingly more NORs, and it seems that mean numbers of NORs should be of prognostic importance. Our study did not indicate the favourable survival of stroma rich cases, and therefore any conclusion based solely on comparison of the studies must be drawn with caution. Our study did, however, show a negative correlation between mean numbers of NORs and survival. The rank correlation was -0.57 and the corresponding $p$ value between 0.05 and 0.02 . Small overall numbers and variable age, stage, and therapeutic regimens tend to obscure even a close relation, but $p$ values of 0.05 or less are considered to be of clinical importance in biological systems. Thus a striking correlation between an established prognostic index (MKI) together with an observed trend toward increased survival with decreased mean numbers of NORs is evidence in support of the prognostic value of NORs in neuroblastomas.

We thank Miss Marna Aitken for secretarial assistance, Dr Mann for access to patient records, and the Leukaemia Research Fund and trust funds of the former United Birmingham Hospitals for financial support.

\section{References}

1 Jaffe N. Neuroblastoma: review of the literature and an examination of factors contributing to its enigmatic character. Cancer Treat Rev 1976;3:61-82.

2 Coldman AJ, Fryer CJ, Elwood JM, Sonley MJ. Neuroblastoma influence of age at diagnosis, stage, tumour, site and sex on prognosis. Cancer 1980;46:1896-901.

3 Shimada $\mathrm{H}$, Chatten J, Newton WA, et al. Histopathologic prognostic factors in neuroblastic tumors: definition of subtypes of ganglioneuroblastoma and an age-linked classification of neuroblastomas. JNCI 1984;73:405.

4 Makinen J. Microscopic patterns as a guide to prognosis of neuroblastoma in childhood. Cancer 1972;29:1637-46.

5 Gitlow SE, Bertani-Dziedzic L, Strauss L, et al. Biochemical and 
histological determinants in the prognosis of neuroblastoma. Cancer 1973;32:898-905.

6 Hughes M, Marsden MB, Palmer MK. Histological patterns of neuroblastoma related to prognosis and clinical staging. Cancer 1974;34:1706-11.

7 Sandstedt B, Jereb B, Eklund G. Prognostic factors in neuroblastomas. Acta Pathol Microbiol Immunol Scand (Sect A) 1983;91:365-71.

8 Kinnier-Wilson LM, Draper GJ. Neuroblastoma, its natural history and prognosis: a study of 487 cases. $\mathrm{Br} \mathrm{Med} \mathrm{J}$ 1974;iii:301-7.

9 Kajanti M, Holsti P. Prognostic factors in neuroblastoma. Annals of Clinical Research 1986;18:129-35.

10 Crocker J, Nar P. Nucleolar organizer regions in lymphomas. $J$ Pathol 1987;151:111-8.

11 Howell W, Black DA. Controlled silver colloid staining of nucleolar organising regions with a protective colloidal developer: a one step method. Experientia 1980;36:1014.

12 Ploton D, Bobichon H, Adnet J. Ultrastructural localisation of nucleolar organising regions in nucleoli of human breast cancer cells using a one step staining method. Biol Cell 1982;43:229-32.

13 Ploton D, Menager M, Adnet J. Simultaneous high resolution localisation of nucleolar organising region protein and nuclear protein in interphase and mitotic nuclei. Histochem $J$ 1984;16:897-906.
14 Crocker J, Skilbeck N. Nucleolar organiser region-associated proteins in melanocytic lesions of skin. A quantitative study. $J$ Clin Pathol 1987;40:885-9.

15 Egan M, Raafat F, Smith K, Crocker J. Nucleolar organiser regions in small cell tumour of childhood. $J$ Pathol 1987; 153:275-80.

16 Egan M, Raafat F, Crocker J, Smith K. Nucleolar organiser regions in fibrous proliferations of childhood and infantile fibrosarcoma. J Clin Pathol 1988;41:31-3.

17 Egan M, Crocker J. Nucleolar organiser regions in tumours of skin and skin adnexae. J Pathol 1988;154.

18 Egan M, Smith K. Expression of $\mathrm{S} 100$ protein in breast lesions. $J$ Clin Pathol 1987;40:1485-6.

19 Egan M, Crocker J, Raafat F, Williams D. Prognostic importance of nucleolar organiser regions in Ewing's sarcoma of childhood. J Clin Pathol 1988;41:232.

20 Shimada H, Aoyama C, Chiba T, Newton W. Prognostic subgroups for undifferentiated neuroblastoma. An immunohistochemical study with an anti-S100 protein antibody. Hum Pathol 1985;16:471-6.

Requests for reprints to: Dr M Egan, Department of Histopathology, The Children's Hospital, Ladywood Middleway, Ladywood, Birmingham B16 8ET, England. 